\title{
The Development Model of School Culture on the Strengthening of Students' Character In SMA Islam Sultan Agung Semarang
}

\author{
Khoirul Anwar', Wasino², Samsudi ${ }^{3}$, Titi Prihatin ${ }^{4}$, Argo Victoria ${ }^{5}$. \\ ${ }^{1,2,3,4,5}$ Graduate School, Universitas Negeri Semarang, Indonesia \\ ${ }^{1}$ Correspodning email: khoirulunissula@ gmail.com
}

\begin{abstract}
The complexity issues of the national crisis character has become a concern of all components. The crisis character or morality is marked by increasing crime and violence in education. That is caused by the process of the character transfer is still not working effectively in the school. Therefore it is necessary to do an effective breakthrough involving educators, community, family and school culture in character education. This study aims to provide an alternative education model school culture based building character during emphasis on curriculum, while the character education based on a school's culture is less developed. This study was designed to use the qualitative approach to research. The products that will be developed in this study is based on strengthening of students character at the high school level. The results showed that the cultivation of students character more effectively through the school culture. Because school is an institution that is very important in establishing the character of the students. In the end, educational institutions must take an active role in the improvement of the national character through the strengthening of students character.
\end{abstract}

Key words: Crisis Character, Islamic School Culture, Building Students’ Character.

\section{Introduction}

Indonesian is currently experiencing a moral decay in virtually all segments of life and all levels of society. It is still common to hear the brawl between learners, the case of drugs that engage learners, and other cases that illustrate the weakness of character of students, especially at the senior high school. Considering they are at the most vulnerable period in encountering cases of juvenile delinquency.

Bad conditions of the national character have encouraged the Government to take the initiative to prioritize the development of national character. Building a national character requires a long time and should be done on an ongoing basis. Through character education which is implemented in educational institutions, the expected character of the nation's crisis can be solved.

Various character education program has been initiated by the government, however, the behaviour of the nation which illustrates the weakness of the nation's character is still the highlight news in the media.

This study diffrent with previous reseachs because will focus on the development model of school culture in SMA Islam Sultan Agung Semarang called Islamic School Culture. Next will be investigated and their implementation on the ground is also supporting and inhibiting factors.
Based on the background, the writer interested to examine the development of the school culture model-based on the strengthening of students character in SMA Islam Sultan Agung Semarang. How is the development model of school culture on the strengthening of student's character in SMA Islam Sultan Agung Semarang? How is the implementation of strengthening the character building based on the school development model in SMA Islam Sultan Agung Semarang?

\section{Methods}

The method used in this study is a qualitative research method through the three data collection techniques are: interview, observation and documentation. The data analysis in this research used interactive model, divided 3 parts; Data reduction, data servicing and verification. This research to observate the training of student's character building and describe the school culture environtment based on Islamic School Culture.

Qualitative analysis is actually a research procedure that produces descriptive data that is what is stated by the respondent in writing or verbally, qualitative analysis is done by means gather the data that have been obtained are then linked with the theories related to the problems examined.

a. Interview 
Data collection through interviews were conducted to collect data on school culture at SMA Islam Sultan Agung Semarang, the development of school culture that has been done so far, supporting factors and obstacles in the implementation of school culture that has been developed and how the strengthening of the character of the students through a school culture that has existed.

On first stage researchers identified people who were interviewed, the selected key informants. Key informants are people who are directly involved in school activities and strengthening the cultural development of learners characters, namely the Principal, Vice Principal and teacher of student affairs of the Islamic Religious Education (PAI). The second phase, preparing for an interview, which is preparing a list of the question while containing subject matter which wants to reveal in the interview. The third stage, conducted interviews with giving the respondent to reveal freely in answering the questions. The fourth stage, stop the interview after the researchers get the necessary information.

\section{b. Obervation}

Observation was conducted in order to observe the events perceived by the subjects and to develop an understanding of social background yang and their complex relationships that exist in it. Observation data collection techniques used when research with regard to human behavior, work processes, natural phenomena observed and if the respondent is not too large.

Observations in this study was the development of school culture that is based on strengthening the character of learners that includes training activities aqeedah, morals, worship, and the attitudes and behavior of learners.

\section{c. Documentation}

Data obtained through the study of the documentation used to supplement the data obtained through interviews and observations. The data consists of the writings and recordings such as handbooks, official reports, minutes of meetings and others. Documentation collected and examined in this study, among others, the school culture development program based on strengthening the character of students, rules and school rules, and other documents that are relevant.
Methods of data collection research using Primary Data. Primary data is data obtained directly on the ground that in this case the authors obtained directly and sourced from interviews, the notion of an interview is a way of collecting data by asking directly to the informant or the competent authorities on issues. And other sources, secondary data source is a data source that does not directly provide information and complementary source of primary data, secondary data generally have been arranged in the form of legislation, papers, in the form of books, journals, articles and theses.

\section{Results and Discussion}

Character education is an education that is formed through the habitual behavior of action and exemplary embodiments of educators, parents, leaders, and communities are spacious environment for the development of the character of the students. School is one institution that heavy burden to implement character education. School as a guard breathed life character education should also focus on the exemplary educators.

In the get building the good character to the learners in SMA Islam Sultan Agung Semarang, educational institution or the school should be aplicate as a school culture to realize the program of building character. This school culture in this level must be develope by the effort of all component as a process of educational in the school. The basic value, traditions, habit, and symbols should be practicing with every members of school and the society.

In the character building need the good management, because it is one an effective media in the character building in the school. The management should be apllied using participative, democratic, elaborative, and explorative, so the all components can feel the significant development.

Many of us are asking, what is wrong with education in our country so that it indicated that the implementation of character education in Indonesia has not fully succeeded? That the failure of it is caused by the process of delivery and transfer of the character is still not effective. To tackle the problem, need to be made various efforts, including the development of the school culture to support the national policy of "national character building". 
Afsya Oktafiani Hastuti in Solidarity: UNNES Journal of Education, Society and Culture, Vol 4 No 2 (2015); "The process of implementing religious character education experienced several obstacles including: differences in student's level of understanding, influence of the environment outside of school, and lack of teacher control over the implementation of religious character education".

Ismail Sukardi in Ta'dib: International Journal of Islamic Education, Volume 21, Number 1, June 2016; "In the Islamic perspective character education paired with akhlaq (Islamic ethics) education. Among the important characteristics are: it sourced from the Quran Hadith; Prophet Muhammad as a role model; priority-based methods of mentalspiritual (soul management, habituation, exemplary, and healthy environment); are simultaneous in which three education centers, namely schools, families, and communities should play a role in synergy. The government and the mass media also play a role in supporting the education of character."

Alvira Pranata (2016) in his research entitled "Culture-Based Character Education Strategy in SMAN 9 Yogyakarta" concluded that the culture-based character education strategy developed teaching strategies, modelling, reinforcement and habituation implemented in culture based school programs. While Fanani (2013) in his article entitled "Investment Value Character Development Through Culture School" concluded that one key to success in order to build good character in the self-learners is any educational institution or school must implement a school culture in order to familiarize the character to be established.

Djailani AR. stated about the "Strategy Character Building of Students at Excellent Schools in the City Of Banda Aceh";

Character Building Goal in simple has stated that the purpose of education is to make human adult learners and responsible as individuals, members of society and as citizens. While more operational as follows: "The purpose of education is to make students" whole man perfect "or" complete human being". About the enlightened one by is: "The achievement of "perfection" is indicated by the formation of "personal morality" or "moral character". The second view of the above it can be concluded that, if implemented consistently education, then education should be directed to the formation of moral individuals. Personal meaning moral individuals who have the ability to manage their lives in accordance with the demands of human values.

The efforts to realize the vision of building the best generation "Khaira Ummah" at SMA Islam Sultan Agung Semarang serve as the basis for the development of a culture model of strengthening character based on Islamic Value, so the development of the school culture model known by the term Islamic School Culture. The result of the development of the school culture focused on the application of Islamic values in the whole life of the school in order to strengthen the character of the students, especially the religious character. Religious as one character value in the form of subservience implementation the teachings of the religion professed. The existence of a religious school culture will develop a character that reached the school, such as care for the environment, strengthen sillaturrahmi, honour, respect, discipline, independence, accountability and integrity.

While the implementation of the results of cultural development in SMA Islam Sultan Agung adequate management and support of the entire school community. To that end, all parties in the school environment should be involved in supporting the implementation of the development of the school culture. Factors that support the successful development of a school culture based reinforcement learners characters are shared commitment to realize the school's vision to build the best generation "Khaira Ummah". The inhibiting factor is the absence of a complete guidebook to be the handle of the school community and preparing the best generation for the nation future who has a best character.

\section{Conclusion}

Development of reinforcement-based school culture model character in SMA Islam Sultan Agung Semarang done by developing a school culture into a culture of Islamic School Culture to provide an alternative education model school culture based building character during emphasis on curriculum and to prepare the best generation in the society in the national 
future through development model of character building based on school culture.

\section{References}

Afsya Oktafiani Hastuti in Solidarity: Journal of Education, Society and Culture, Vol 4 No 2 (2015)

Approaches to the Development of Character, Richard $\quad$ M. Lerner, Deborah Lowe Vandell, and Jonathan M. Tirrell Journal of Character Education, Vol. 13 \#1, 2017

Berliner D 1985 Laboratory settings and the study of teacher education Journal of Teacher Education 366 p 2-8

Character Under Attack and What You Can Do About It, by Carl Sommer (2006) Reviewed by Michael Hylen, Association for Character Education (2016). 9 Principles. Online. Available: http://www.charactereducation.org.uk/9-principles [28 March, 2017].

Character.org (no date). 11 Principles of Effective Character Education. Online. Available: http://info.character.org/11principles-download [28 March, 2017].

Fanani, Z (2013) Investment Value Character Development Through Culture School (AlHikmah: Volume 3 no. 2.) September 2013

Miles MB, Hubber, A.M. (2010) Qualitative data analysis, Baverley Hills.
Illuminating the Mechanisms of Character Development (A Response to Berkowitz, Bier, \& McCauley) Camille A. Farrington Journal of Character Education, Vol. 11 \#2, 2015

Ismail Sukardi in Ta'dib: Journal of Islamic Education, Volume 21, Number 1, June 2016

Jubilee Centre for Character and Virtues (no date). Framework for Character Education in Schools. Jubilee Centre for Character and Virtues [online]. Available:http://jubileecentre.ac.uk/userfiles/ jubileecentre/pdf/othercentrepapers/Framework..pdf [28 March, 2017].

Strategy Character Building of Students at Excellent Schools in the City Of Banda Aceh Djailani AR, FKIP Universitas Syiah Kuala Banda Aceh. IOSR Journal of Research \& Method in Education (IOSRJRME) e-ISSN: 2320-7388,p-ISSN: 2320737X Volume 1, Issue 5 (May. -Jun. 2013), PP 49-59 www.iosrjournals.org www.iosrjournals.org.

Toward a Science of Character Education: Frameworks for Identifying and Implementing Effective Practices, Marvin W. Berkowitz, Melinda C. Bier, and Brian McCauley Journal of Character Education, Vol. 11 \#2, 2015. 